\title{
Sobre el Fuero extenso de Mérida
}

\section{About the Merida's extensive Fuero}

\author{
Pedro Andrés PORRAS ARBOLEDAS \\ Catedrático acreditado de Historia del Derecho \\ Departamento de Historia del Derecho \\ Instituto de Metodología e Historia de la Ciencia Jurídica \\ Facultad de Derecho. Universidad Complutense de Madrid \\ pporras@der.ucm.es
}

Recibido: 7 de mayo de 2012

Aceptado: 22 de junio de 2012

\section{RESUMEN}

Hasta la fecha se conocía el fuero breve concedido a la antigua capital de la Lusitania, una vez reconquistada de manos de los musulmanes; hoy es posible afirmar claramente la existencia de un Fuero extenso, al menos hasta la primera mitad del siglo XVI, pues para 1633 se había perdido la noción del mismo. En este artículo se da noticia de dicho Fuero extenso y de los privilegios que pudieron conformarlo, de acuerdo con los otorgados por los maestres santiaguistas.

PALABRAS CLAVE: Ciudad de Mérida. Fuero extenso. Fuero breve. Privilegios. Orden de Santiago.

\begin{abstract}
To the date, we had access only to the charter -"fuero"- granted to the ancient capital of Lusitania, once re-conquered by the Muslims. Today it is possible to state clearly the existence of an extensive Fuero, in order until the first half of the sixteenth century at least, and whose track was lost by 1633 . This paper gives notice of such extensive Fuero and the privileges that could conform it, according to those granted by the masters of the Santiago Order.
\end{abstract}

KEYWORDS: City of Merida. Extensive Fuero. Short Fuero. Privileges. Santiago Order's.

\section{RÉSUMÉ}

À ce jour, on connaissait seulement la charte brève accordée à l'ancienne capitale de la Lusitanie, une fois elle a été reconquise aux musulmans ; aujourd'hui il est possible d'affirmer clairement l'existence d'une charte vaste, au moins jusqu'à la première moitié du XVI ${ }^{\mathrm{e}}$ siècle, car en 1633 on avait perdu sa trace. Cet article donne avis de cette charte vaste et des privilèges qui pourraient l'avoir conformé, à partir de ceux accordés par les maîtres de l'Ordre de Santiago.

MOTS CLÉ : Ville de Merida. Charte Vaste. Charte Brève. Privilèges. Ordre de Santiago.

\section{ZUSAMMENFASSUNG}

Bis zum jetzigen Zeitpunkt kannte die Forschung lediglich den kurzen Fuero, der der antiken Hauptstadt Lusitaniens nach der Reconquista gewährt worden war; heute ist es unterdessen möglich, die Existenz eines ausführlichen Fuero herzuleiten, zumindest bis zur ersten Hälfte des 16. Jahrhunderts, denn bis 1633 war letzterer in Vergessenheit geraten. Dieser Artikel beleuchtet diesen ausführlichen Fuero (Fuero 
extenso) und die Privilegien, die ihn im Einklang mit den von den Hochmeistern des Sankt-JacobusOrdens gewährten Vorrechten ausgestalteten.

SCHLÜSSELWÖRTER: Stadt Mérida, ausführlicher Fuero (Fuero extenso), Fuero in Kurzfassung, Privilegien. Santiago-Orden.

Son muy numerosos los fueros breves medievales conservados en el área castellana, datables ya desde época antigua, sin embargo, no puede decirse lo mismo de las redacciones más amplias, conocidas como Fueros extensos; para ello sólo hay que recurrir al Catálogo preparado hace algunos años por Ana Barrero y Mari Luz Alonso. ${ }^{1}$ Si nos referimos al caso de Mérida, según dicho Catálogo, no se conoce el Fuero extenso, no así el fuero breve de 1235 o el privilegio por el que se ampliaban sus contenidos, de 1327; nada más. ${ }^{2}$ En las líneas que siguen, luego de pasar revista a dicho fuero breve y los privilegios recibidos por la ciudad durante la Baja Edad Media, aportaremos testimonio de 1537 sobre la existencia de un Fuero extenso e intentaremos identificarlo, de acuerdo con los otros concedidos en la zona. Debe tenerse presente que cuando Moreno de Vargas redactó su obra (1633) se había perdido constancia de dicho texto; es más, este autor ni conocía siquiera el fuero breve, conservado, eso sí, en los archivos de la Orden de Santiago. ${ }^{3}$

En efecto, la historia de la ciudad de Mérida no es la de una localidad cualquiera, aunque sólo fuera por la relevancia con que había contado en la Antigüedad; ${ }^{4}$ la Mérida medieval sólo será un remedo discreto de la antigua Emérita Augusta, tanto en época musulmana como en la cristiana bajomedieval, sin embargo, el hecho de haber sido sede metropolitana despertó, como es bien sabido, las apetencias del obispo de Santiago de Compostela, don Diego Gelmírez, que en 1119 consiguió la traslación de dicha sede de la Mérida ocupada por los árabes a su obispado compostelano. ${ }^{5} \mathrm{Na}-$

\footnotetext{
${ }^{1}$ Textos de derecho local español en la Edad Media. Catálogo de Fueros y Costums municipales, Madrid, 1989. La referencia a los fueros de Mérida en página 301.

${ }^{2}$ El fuero de población (1235) vendría, según estas autoras, recogido en el Bulario de la Orden (Antonio F. Aguado de Córdova, Alfonso A. Alemán Rosales y José López de Agurleta, Bullarium equestris ordinis S. Jacobi de Spatha ..., Madrid, 1719, no 4, pp. 106-107); Bernabé de Chaves, Apuntamiento legal sobre el dominio solar ..., Madrid, 1740 (reimpresión, Barcelona, 1975), fol. 33v-34r; J.V. Corraliza, «Geografía extremeña», Revista de Estudios Extremeños, IV, 1930, pp. 99-102, y Vicente Navarro del Castillo, Historia de Mérida y pueblos de su comarca, Cáceres, 1972, II, pp. 38-40.

El privilegio de 1327, por su parte, está editado tanto en el trabajo de Navarro (pp. 43-44), como en el de Bernabé Moreno de Vargas, Historia de la ciudad de Mérida, Madrid, 1633 (4 reedición, Badajoz, 1984), pp. 385-387.

${ }^{3}$ Moreno, pp. 394-395.

${ }^{4}$ Las provisiones del Consejo de Órdenes de la época de Carlos I, conservadas en el Archivo Histórico Nacional de Madrid, que en la actualidad estoy investigando, además de arrojar los documentos que publico en el apéndice, son una fuente generosa de referencias sobre el pasado romano, tanto de la ciudad de Mérida, como de otras localidades, como Segóbriga (Cabeza de Griego), dependiente de la villa conventual de Uclés.
}

${ }^{5}$ Bula de Calixto II, editada por Moreno, pp. 350-352. 
turalmente, a partir de ese momento el interés de los arzobispos compostelanos pasó por mantener el statu quo, impidiendo por todos los medios la reinstauración de dicha sede emeritense; por ello, cuando a comienzos del siglo XIII el monarca leonés Alfonso IX se planteó la conquista de las tierras de la actual Extremadura, allá anduvo el arzobispo don Bernardo junto al Rey. Al parecer, antes de la conquista definitiva de Mérida, la ciudad había entrado en la órbita de los caballeros de Uclés, pues se documenta un comendador de Mérida, de nombre Ramiro Fruela, en los inicios de esa centuria; poco después, en torno a 1210 el maestre santiaguista don Pedro Arias anduvo haciendo la guerra a los moros cacereños y emeritenses, sin un éxito concluyente, que no se produciría hasta 1229 , en que el último rey leonés tomó Cáceres, y 1230, en que hizo lo propio con Mérida; poco después caería Montánchez. ${ }^{6}$

Así pues, al rey Alfonso se le planteaba una disyuntiva sobre el destino a dar al señorío de tan ilustre sede; el arzobispo podía hacer valer la donación que había recibido de la misma de manos de Fernando II, padre de Alfonso, en tanto que el maestre alegaba que debía ser suya, ya que la había tomado años antes, aunque luego la perdiera. El soberano decidió, finalmente, hacer honor a la palabra dada por su progenitor y donó (pro anima sua) la ciudad con todas sus pertenencias a don Bernardo, quien de este modo conseguía evitar que se erigiese en ella siquiera un obispado; el privilegio confirmatorio de la donación paterna se expediría cerca del castillo de la Atalaya, en 2 de junio de 1229, durante el cerco. ${ }^{7}$ En la misma donación se fijaban los términos de su alfoz, pormenorizadamente, ${ }^{8}$ y se detallaban, como era habitual, todas las pertenencias (derechos, montazgos, portazgos, prados, pastos, montes, fuentes, entradas y salidas). Se le imponía como obligación el hacer guerra, paz y tregua de orden del Rey y se le daba privilegio de inmunidad, prohibiendo actuar dentro de sus términos al merino o al sayón reales. Todo ello a fin de merecer la gracia de las oraciones que se hiciesen en dicha iglesia compostelana, tanto por su alma como por la de sus predecesores.

Sin embargo, mantener una ciudad en primera línea de la frontera no debía de ser nada fácil para un prelado radicado en tierras gallegas, lejos del teatro de operaciones;

\footnotetext{
${ }^{6}$ Moreno, pp. 365-370. Sobre la conquista de la ciudad, «De la frontière mythique á la frontière conquise: Alphonse IX de Léon et la prise de Mérida», Cahiers de linguistique et de civilisation hispaniques médiévales, XXVII, 2004, pp. 311-328.

Véase, especialmente, Miguel A. Ortí Belmonte, Las conquistas de Cáceres por Fernando II y Alfonso IX de León y su fuero latino anotado, Badajoz, 1947.

${ }^{7}$ El documento latino de la donación de 1229 también está recogido en el Apuntamiento de Chaves, fol. $5 \mathrm{v}-6 \mathrm{v}$.

${ }^{8}$ Al tiempo de Moreno de Vargas, el alfoz emeritense contaba con 13 lugares: Alguijuela -hoy Torremayor-, Aljucén, Calamonte, Carmonita, El Carrascalejo, Cordovilla —hoy Cordobilla de Lácara-, Esparragalejo, Mirandilla, Nava — hoy La Nava de Santiago-, San Pedro — hoy San Pedro de Mérida-, Santa Ana — junto a La Nava, no existe hoy día como municipio-, Torremejía y Trujillanos. Se habían emancipado las villas de Lobón, Montijo y Puebla de la Calzada (Moreno, pp. 438-443 y 456-463).
} 
ya que se había abortado la posibilidad de que se reerigiese la sede emeritense, el arzobispo podía actuar con benevolencia frente al maestre santiaguista, que sí estaba en buenas condiciones de defender la ciudad de la morisma. Así, en 1232 Fernando III tuvo ocasión de aprobar el acuerdo a que habían llegado ambas partes; según éste, el arzobispo se reservaba la jurisdicción eclesiástica de la ciudad, quedando la defensa en manos del maestre — si la guerra durase más de 4 años, el prelado se comprometía a suministrar anualmente a la Orden 2.500 áureos-; la ciudad, con sus términos, rentas, quintos y demás pertenencias, se dividía a partes iguales entre arzobispo y maestre.

La solución adoptada no parece que resultase muy operativa, cuando en 1234 ambas partes acordaron una permuta de propiedades: la Orden de Santiago se quedaba con la otra mitad de la ciudad — que quedaba ahora bajo su exclusivo señorío $-y$, a cambio, entregaba al prelado el monasterio de Loyo, en Galicia, además de las casas que tenía la Orden en Santiago de Compostela. ${ }^{10}$ De este modo, se imponía la realidad, pues los santiaguistas redondeaban sus posesiones extremeñas, en un medio que les era familiar, mientras que los arzobispos se desprendían de un lugar lejano, de mantenimiento engorroso, una vez que habían conseguido afianzar la sede compostelana.

No obstante, debe de haber algún error en las fechas que venimos manejando - Moreno de Vargas, a diferencia de los otros documentos que glosamos, no inserta ni el texto de la cesión de 1232 ni el del trueque de 1234-, pues el fuero breve concedido a la ciudad en 1235 fue otorgado por el arzobispo don Bernardo, con consenso de los miembros de su iglesia y de don Rodrigo Íñiguez, comendador del Reino de León, en nombre del maestre don Pedro González. ${ }^{11}$ Estimo como más probable que la permuta fuese algo posterior al otorgamiento de este fuero.

En cualquier caso, los condueños, en la fecha expresada, concedieron fuero a los habitantes de la ciudad de Mérida y de su término, presentes y futuros, en el que se contenía un conjunto de diez disposiciones:

$1^{\circ}$ ) obligación de pagar portazgo a todos los vecinos de Mérida y sus aldeas de lo que trajesen o llevasen a tierra de sarracenos, salvo lo destinado a la redención de alguno de ellos o a la alimentación de los mismos.

$2^{\circ}$ ) atribución a arzobispo y maestre, así como al futuro obispo, del tercio de las tierras de la ciudad y su término (prados, ríos, arroyos, huertos y salidas), quedando la parte restante para los vecinos; de esa parte, un tercio quedaría para los habitantes actuales y el otro para los futuros. Se prohibía a los vecinos enajenar esas posesiones sino a otros vecinos, que fueran vasallos del arzobispo o del maestre.

\footnotetext{
${ }^{9}$ Véase José Luis Martín, «Mérida medieval: el señorío santiaguista», Revista de Estudios Extremeños, LII-2, 1986, pp. 487-496. Este proceso también es glosado, siguiendo el trabajo anterior, por José Antonio Ballesteros, «Mérida, clave en la fundación de la Orden de Santiago», Espacio, Tiempo y Forma, III, Historia Medieval, XVII, 2004, pp. 53-66, en especial, en las últimas seis páginas. También Manuel López Fernández, «Mérida y la Orden de Santiago en las décadas centrales del siglo XIII (1231-1274)», REE, XLV-1, 2009, pp. 257-312.

${ }^{10}$ Moreno, pp. 370-379.

${ }^{11}$ Sigo el texto latino editado por Chaves (fol. 33v-34r), donde se expresa la data: Facta carta huius Fori apud S. Iacobum, .XV. Kalendas augusti, sub Era .MCCLXXIII.
} 
$3^{\circ}$ ) atribución de la mitad del montazgo a prelado y maestre y del resto a los vecinos, con obligación de guardar los montes todos ellos.

$4^{\circ}$ ) atribución de dehesas de conejos (De nemoribus vero cuniculorum) al arzobispo y maestre y a los vecinos, por separado, debiendo custodiar cada uno las suyas.

$5^{\circ}$ ) abono de penas y caloñas según el Fuero de Cáceres, a repartir por tercios entre prelado y maestre, querelloso y alcaldes.

$6^{\circ}$ ) designación anual de alcaldes por prelado y maestre, con consenso de los hombres buenos de la ciudad, entre los que habitasen la misma y su término u otros que fuesen vasallos de arzobispo o maestre (vel de caetero morabuntur, sint vassalli...); deberían jurar que serían fieles y justos.

$7^{\circ}$ ) obligación de abonar los vecinos de la ciudad y su término al arzobispo y los caballeros el quinto de las cabalgadas, salvo el requinto de las aldeas y el séptimo de los jueces. Se trata, al menos, de una cláusula añadida al fuero (Additur in hic foro).

$8^{\circ}$ ) concesión a cada vecino de Mérida de una aranzada de viña, como las tenían a la fecha justamente, con tal de que pagasen diezmos y primicias a sus iglesias.

$9^{\circ}$ ) procedimiento judicial: en primera instancia conocerían los alcaldes de la ciudad, yendo sus alzadas al libro que tenían, según el uso de Cáceres (si quis voluerit alciare se ab eis, alciet se ad librum sive forum, quem librum ipsi cives habent de iudiciis secundum usum de Canceres); el tercio de las penas se aplicaría a los condueños. De la solución emanada del libro podían apelar ante el comendador o el que éste dejare en su lugar; de la sentencia del comendador debían alzarse ante el arzobispo o ante quien éste diputase; en esa instancia fenecería el procedimiento.

$10^{\circ}$ ) prelado y caballeros elegirían a los dos alcaldes de la ciudad, llamados vulgarmente uno de concejo y otro de hermandad.

Se añadía que el fuero sería mantenido por los otorgantes siempre que los emeritenses fueran vasallos buenos y diligentes, les sirviesen y observasen lo que debían a sus señores. Firmaban el documento arcediano, escolar, tesorero y juez de la iglesia compostelana, tres sujetos (Pedro Ordóñez, Juan Peláez y Miguel Díaz), cardinales compostellani, dos personas más sin filiación (Pedro Pérez de Berruecopardo y Lorenzo Viene de Vinal), el comendador santiaguista Suero Díaz y los ciudadanos de Mérida Raimundo de Segura, Pedro Velasco, Pedro Jacob y Pedro Suárez. Suscribió el otorgamiento Muño Martínez clérigo, de orden del prelado y del comendador Rodrigo Íñiguez.

Pues bien, una simple lectura del texto ya indica que estamos en presencia, bien de un fuero ampliado luego de su primera concesión, bien de una interpolación en el texto original. Como nos advierte el documento a partir de la disposición séptima, se trata de una adición posterior al fuero inicial, de otro modo, por ejemplo, no se entendería que hubiera dos disposiciones distintas sobre la elección de los alcaldes de la ciudad (§ 6 y 10). En cualquier caso, al propósito que aquí nos ocupa, lo más interesante es la mención del capítulo $9^{\circ}$ sobre el fuero o libro que tenían para los juicios, al uso de Cáceres. ${ }^{12}$ Esto indicaría que la supuesta interpolación no estaría muy cer-

\footnotetext{
${ }^{12}$ En el fuero concedido a Montánchez en el Capítulo de Zamora (08/11/1236) el maestre Pedro González establece y por tal foro qual foro y qual fonsadera y qual facendera feceron e los de Cáceres al Rey, tal y quando los feceren, tal fagan e los de Montánchez a la Orden (Chaves, fol. 35r). La carta fue redactada en Villafáfila.
} 
cana a la fecha de concesión del fuero inicial, pues existía un libro (Fuero extenso) inspirado en el Fuero de Cáceres, entendemos que también de carácter extenso. Volveremos sobre la cuestión más adelante.

Tan importante localidad, con un alfoz tan amplio y, a la postre, con una zona de influencia más allá de su término, no podía dejar de concitar la atención de los sucesivos maestres de la Orden, que, como se verá, procuraron privilegiar a su ciudad, ya que durante mucho tiempo Mérida sería la única población que contaría con ese título dentro de las posesiones santiaguistas. Incluso Fernando IV, haciendo uso de sus prerrogativas reales (regalías), concedió a Mérida dos ferias anuales, ambas de 15 días, por San Martín y a mediados del mes de marzo; los concurrentes estarían exentos de pagar portazgo, tanto en la ciudad como en sus términos (privilegio rodado dado en Ciudad Rodrigo, 27/03/1295). ${ }^{13}$

Pero, como digo, fueron los maestres, en el ámbito de sus propias competencias, provenientes de la concesión de inmunidad que habían recibido de manos de Fernando III, quienes se empeñaron en dotar a Mérida de un régimen especial, que favoreciese su poblamiento y engrandecimiento. El primer maestre del que tenemos constancia documental de su implicación en este esfuerzo fue Garci Fernández (13181327): además de confirmar el fuero de población, mercedes y privilegios, usos y costumbres, estableció que aquellos de los ganados maestrales que causasen daños en las heredades emeritenses pagasen las mismas penas que los de los particulares. Además, prohibió al comendador mayor de la ciudad que tomase libremente los suministros que necesitase para su manutención, tras ordenarlo así a los alcaldes; por el contrario, debería enviar a un hombre suyo, quien debería abonar el precio de lo que precisase. Concedía otros privilegios, además, que el escribano no consideró oportuno transcribir. ${ }^{14}$

Pero, como en tantas otras ocasiones, sería don Vasco Rodríguez Coronado (13271338) quien impulsaría esa política; sabemos que concedió dos privilegios: uno primero, fechado en Medina, en 18/04/1327, por el que confirmaba el fuero de población, que ya hemos considerado, así como sus usos y costumbres, mercedes y privilegios recibidos del Capítulo y de los maestres de la Orden. No es posible discriminar si se trataba de una alusión a cuestiones concretas o bien era una referencia genérica. Donde sí fue detallista fue en la concesión de sus aldeas (Aldea del Rubio, Montijo, puerto de Carmonita, Cordovilla y Almendralejo), que debían ser las que en aquellos momentos existían dentro del alfoz; los aldeanos de dichos lugares debe-

\footnotetext{
${ }^{13}$ Moreno, pp. 379-381. Todos los privilegios emeritenses recogidos por este autor proceden de la confirmación llevada a cabo por los Reyes Católicos en el Capítulo general de Tordesillas de 1494.

Esta institución ha sido estudiada por Francisco Morgado Portero, «Las ferias de Mérida: una avanzadilla del urbanismo de la ciudad», Congreso Ciudades históricas vivas, Ciudades del pasado. Pervivencia y desarrollo. Ponencias y comunicaciones, Mérida, 1998, II, pp. 423-431, y Las ferias de Mérida, Mérida, 2001.

${ }^{14}$ Moreno, p. 391.
} 
rían obedecer al concejo emeritense y pagar allí sus tributos, según su Fuero manda. Así mismo, las fechorías de los pobladores de las aldeas deberían ser juzgadas por los alcaldes de la ciudad.

El concejo de villa y tierra gozaría de la bellota, la madera y la leña de la Albuhera de Fernán González, así como de la madera de Las Tiendas ${ }^{15}$ y de las dehesas de Cornalbo, Fresneda y Las Alcazabas, assí como mejor e más cunplidamente lo ovieron e usaron dello en tienpo del maestre don Juan Osórez (1293-1311). Más importante aun fue la prohibición de que el comendador, el subcomendador o el alcaide de Mérida entrasen en los cabildos del municipio, de modo que no interviniesen en la hechura de sus ordenanzas o posturas, o en la designación de los montaraces que guardasen sus montes, para que el concejo tomase sus decisiones de acuerdo con el servicio de la Orden y el pro común de los vecinos. También se prohibía a aquellos cargos de la Orden contradecir los acuerdos tomados en cabildo. Si algún vecino mereciese castigo, no serían los hombres de la Orden los que actuasen, sino que los alcaldes de la ciudad debían tomarlos presos, ponerlos en la cárcel municipal y actuar con fuero y con derecho: los que merecieran pena de muerte u otra, la recibirían (el que mereciere pena o justicia, que gela den); los que no, podrían ser libres, respondiendo con sus bienes, y los que no los tuvieren, dando fiadores. ${ }^{16}$

Un segundo privilegio concedido por don Vasco pretendía mediar entre los intereses del comendador y sus encomendados; así, permitió que aquél percibiese la quinta parte de los bienes de aquellos vecinos que muriesen intestados, pero, antes de computarse esa porción, debían deducirse las deudas del caudal, lo que parece ser que no se venía observando por los comendadores; esto suponía un mal uso. Así mismo, permitía a los de Mérida sacar leña seca de Las Tiendas y del término de Alange y pescar en el Guadiana, salvaguardando los derechos del comendador de esa villa (el comendador de la Casa). ${ }^{17}$

El siguiente privilegio, debido a don Alonso Méndez de Guzmán (1338-1342), es la respuesta positiva del maestre a las quejas presentadas por los vecinos de Mérida y su tierra, que protestaban de que los pastores de los ganados del maestre, del comendador, de otros caballeros de la Orden y de otros hombres poderosos entraban en sus tierras de cereal y viñas, estragándoselas y justificándose diciendo que eran suyas; además, comían la bellota de sus dehesas antes de que fuesen desacotadas y quemaban la tierra para hacer granillo ${ }^{18}$ para sus puercos, de modo que les quitaban dónde llevar

\footnotetext{
${ }^{15} \mathrm{Al}$ parecer, este pago rústico estaba enclavado sobre una villa tardorromana (José María Álvarez Martínez, «La villa romana de "El Hinojal” en la Dehesa de "Las Tiendas" (Mérida)», Noticiario arqueológico hispánico, IV, 1976, pp. 433-488, y «Un mosaico con escena de cacería procedente de la villa romana de "Las Tiendas" (Mérida, Badajoz)», Crónica del XIV Congreso Nacional de Arqueología, Vitoria, 1977, pp. 843-850).

${ }^{16}$ Moreno, pp. 385-386.

${ }^{17}$ Contenía otros privilegios más, no reproducidos por el escribano; no se menciona la fecha del documento (Moreno, p. 392).

${ }^{18}$ Según el diccionario de la RAE, «Harina de trigo sin florear».
} 
sus propios ganados, viéndose en la necesidad de arrendar dehesas fuera de la jurisdicción de la Orden. Ordenó don Alonso que a dichos pastores se les aplicase el fuero (segund su Fuero manda e segund que esto e otras cosas mejor e más cunplidamente se contiene en el dicho privilegio), esto es, que se ejecutase la persona y bienes de los infractores. ${ }^{19}$

Por su parte, el Infante-maestre don Fadrique (1342-1358) sólo confirmó una de las dos cartas ya mencionadas de don Vasco Rodríguez. ${ }^{20}$

Más enjundia tuvo la actividad del maestre don Fernando Osórez (1371-1383): el principal de sus privilegios fue el de revalidar la vigencia de todas las cartas anteriormente recibidas por el concejo de Mérida, pues por razón de las guerras que avían pasado [el tránsito del reinado de Pedro I al de su hermanastro y asesino, Enrique II] que les fueron tirados e quebrantados los sellos de algunos privilegios que tenían de los maestres, nuestros antecesores, que Dios perdone, en que les fazían merced. Así mismo, a petición de los beneficiarios, mandó guardar el ejido de los ganados de la ciudad, protección que hizo extensiva contra los ganados maestrales y de cualesquier otros rebaños, según se había guardado en tiempos del Infante-maestre don Fadrique. Por otro lado, también a instancias de los peticionarios, dispuso que pudiese seguir sacando libremente leña seca de Las Tiendas y del término de Alange, aunque, si cortasen leña verde, deberían pagar en pena $60 \mathrm{mrs}$. por el pie, 20 por el brazo y 4 por la rama. De nuevo confirmó también el derecho a pescar en el Guadiana, respetando los derechos del comendador.

Como era habitual, nada más asumir el maestrazgo don Pedro González Cabeza de Vaca (en Llerena, 09/02/1383) confirmó tanto el fuero de población, privilegios y costumbres, como las mercedes de los maestres don Garci Fernández, don Vasco Rodríguez, don Alonso Méndez de Guzmán, del Infante-maestre don Fadrique y de don Fernando Osórez, que acabamos de glosar. ${ }^{21}$

A pesar de que los privilegios que venimos comentando fueron los que finalmente quedaron recogidos en el elenco conservado y confirmado repetidamente en años posteriores, es evidente que no representan la totalidad de los recibidos, como resulta claro en el concedido a fines del siglo XIV por otro de los grandes maestres de la Orden, don Lorenzo Suárez de Figueroa (Guadalcanal, 03/06/1396): la carta iba dirigida a Ruy Martínez de Céspedes, comendador de Mérida, de quien sus encomendados de la ciudad le habían hecho llegar un buen puñado de quejas: se entrometía en los cabildos del ayuntamiento, perturbándoles en la aprobación de sus ordenanzas e interviniéndoles sus bienes de propios y rentas; los vasallos presentaron para ello los privilegios de que gozaban, así que el maestre no tuvo más remedio que prohibír-

\footnotetext{
${ }^{19}$ Moreno, pp. 392-393.

${ }^{20}$ Ibidem, p. 393.

${ }^{21}$ Idem, pp. 391-393. Añade el autor «De lo contenido en esta carta ... se prueba que Mérida tuvo fueros en su población, mas de ellos, como de otras cosas suyas, no tenemos otra noticia que la referida» (pp. 393-394).
} 
selo al comendador, con una excepción: salvo si llegáredes a los tales concejos e ayuntamientos por requerir al dicho concejo e homes buenos de nuestra parte sobre algunas cosas que cunplen a nuestro servicio.

Mayor indignación levantó en el ánimo del maestre la noticia de que Céspedes, además de vulnerar los fueros y los privilegios de la ciudad, obligaba a los vecinos del castillo a dar posadas a quien quería, lo que contradecía directamente un privilegio - para nosotros desconocido- dado por él mismo en sentido contrario (e desto somos mucho maravillados por lo vos assi fazer, mayormente sabiendo cómo nos les fezimos merced e les dimos privilegios que non passassen ningunas personas en el dicho castillo). Por todo ello, don Lorenzo confirmó todos los privilegios que tenían los de Mérida.

En consonancia con la política iniciada por Enrique II, a fin de hacer frente a las consecuencias de la Peste Negra, el maestre Suárez de Figueroa decidió dejar en suspenso durante dos años la disposición canónica, traspuesta a la legislación real, que prohibía a las mujeres viudas contraer nupcias durante el primer año tras la muerte de su consorte. Como es bien sabido, esto se hacía para evitar la turbatio sanguinis, de forma que se conociera con claridad la paternidad de sus vástagos. Justificaba dicha suspensión considerando el gran danno que han recibido, assi por la gran pestilencia que Dios sobre la gente quiso echar, como por las guerras que han sido en estos tienpos passados; la norma iba dirigida tanto a las viudas capitalinas como a las de las aldeas, tanto a las que habían enviudado ya como a las que lo hiciesen dentro de ese bienio. ${ }^{22}$

Del prolífico, en lo que se refiere a la emisión de mandatos, Infante-maestre don Enrique de Aragón (1409-1445), el autor que venimos citando recoge una serie de provisiones:

— orden al lugar de la Puebla de Sancho Pérez de abonar a Mérida la cebada de la yuntería (Mérida, 07/03/1412).

- orden al comendador Ruy Martínez de Céspedes de no entrometerse en las actividades del concejo y guardar sus privilegios y costumbres (Valladolid, 09/05/1416).

— orden al comendador Garci González de Céspedes de cumplir las cartas del maestre Suárez de Figueroa ( $\sin$ citar datas).

- orden al mismo comendador de permitir al concejo ceder solares para casas y aheridos para molinos, según su costumbre (Guadalajara, 20/02/1420).

- orden al mismo comendador de no entrometerse en las elecciones de oficiales de concejo, ni formar bandos ni parcialidades para ello (Ávila, 04/10/1420). ${ }^{23}$

Del período del Infante se conservan tres sentencias de los visitadores de la Orden, a su paso por Mérida: una de ellas, pronunciada en 05/11/1426, a petición del concejo, en que condenaba a Ruy Sánchez Hurtado, alcaide de Cubillana, a que permitiese a

\footnotetext{
${ }^{22}$ Moreno, pp. 396-397.

${ }^{23}$ Estas provisiones se conservaban en el archivo municipal y estaban confirmadas por los Reyes Católicos (Moreno, p. 399).
} 
los emeritenses coger uvas y moras, cortar madera y leña, cazar, segar yerba y tomar la bellota de las dehesas de Araya ${ }^{24}$ y Las Tiendas y en la Isla de Juan Antón, pues tenían posesión inmemorial de hacerlo. La segunda fue dictada tan sólo trece días más tarde, a requerimiento de cuatro vecinos de la ciudad, condenando al comendador y a su administrador a «que no cobre la cuarta, aunque sea de jornaleros, pagando su diezmo y primicia, y que no lleven poya a los labradores». La tercera fue fulminada el día 20 del mismo mes, teniendo como contendientes al comendador y al concejo y como objeto las llaves del castillo: ${ }^{25}$ la ciudad había demostrado estar en posesión de costumbre de tener la llave de la puerta de hierro del castillo, a fin de que los vecinos pudieran salir a labrar cuando les pareciere, máxime cuando el castillo tenía fortaleza de homenaje apartada; en tiempos de paz tendría la llave el concejo o quien éste diputase; en tiempo de guerra pregonada lo tendría en la noche el comendador, si se hallare dentro del castillo, y de día el concejo; si no estuviera en la ciudad el comendador, el concejo discerniría persona que se hiciera cargo. ${ }^{26}$

En el futuro ya no se concederían nuevos privilegios; nada sabemos de la época del condestable don Álvaro de Luna como maestre, pero de su adversario, don Juan Pacheco, marqués de Villena, sólo se conserva la confirmación de todas las mercedes, privilegios, franquicias, libertades, sentencias de visitadores, fueros, buenos usos y costumbres, leyes capitulares, aranceles y establecimientos recibidos por Mérida de sus predecesores (Los Santos de Maimona, 22/10/1469). ${ }^{27}$

Todos los privilegios y confirmaciones que hemos citado hasta aquí serían trasladados y confirmados por el último maestre santiaguista, don Alonso de Cárdenas, en el Capítulo general celebrado en el Corral de Almaguer (15/05/1480); a mayor abundamiento, validó expresamente el fuero de población, así como los privilegios, sentencias y mercedes trasladados antes. ${ }^{28}$ Ahí quedó petrificado el elenco de cartas privilegiadas recibidas por los emeritenses, las cuales, a su vez, serían confirmadas a la letra por los Reyes Católicos, en su calidad de administradores de la Orden, en el Capítulo general de Tordesillas (06/06/1494). Se establecía una cláusula condicional: los privilegios deberían haber estado vigentes en los últimos 40 años. ${ }^{29}$

\footnotetext{
${ }^{24}$ También esta dehesa encerraba restos de la Antigüedad (Juan J. Enríquez, «Avance al estudio de los materiales procedentes de Araya, Mérida (Badajoz)», Pyrenae: Revista de prehistòria i antiguitat de la Mediterrània Occidental, XVII-XVIII, 1981-1982, pp. 191-202).

${ }^{25}$ Sobre las murallas de la ciudad, Felipe Valbuena, «Notas sobre la cerca de Mérida en el siglo XVI», REE, XXXVII-1, 1981, pp. 67-93, y Miguel A. Alba, «Acerca del foso medieval de Mérida», Mérida. Excavaciones arqueológicas, V, 1999, pp. 165-188. Sobre la fortaleza, Santiago Feijoo y Miguel A. Alba, «El sentido de la Alcazaba emiral de Mérida: su aljibe, mezquita y torre de señales», Mérida. Excavaciones ..., VIII, 2002, pp. 457-486, y Manuel Garrido, «Notas sobre la fortaleza santiaguista de Mérida antes de ser conventual», Norba-Arte, VI, 1985, pp. 43-64 (trabajo basado en la visita de 1498).

${ }^{26}$ Moreno, pp. 400-401.

${ }^{27}$ Ibidem, pp. 404-405.

${ }^{28}$ Idem, pp. 414-415.

${ }^{29}$ Sobre la administración económica en este período, véase Pablo Iglesia Aunión, «La política económica de los Reyes Católicos en la Orden Militar de Santiago: la Mesa Maestral en la encomienda de
} 
Desde el momento en que los Reyes accedieron a la administración, por autoridad apostólica (1493), decidieron que en Mérida, en consideración a su relevancia histórica, hubiera un corregidor, quedando fuera de la jurisdicción del gobernador de la Provincia de León; pero esta situación duró poco, por cuanto, pasados seis años (Granada, 11/08/1499), emitieron una cédula para el Dr. Nicolás Tello, miembro del Consejo de la Orden, en su calidad de juez de residencia de dicha Provincia —incluyendo los corregimientos de Mérida y Jerez de los Caballeros-, para que, una vez cumplido el plazo de 90 días, dentro del cual debía enjuiciar el mandato del gobernador Luis Portocarrero y de sus oficiales, pusiera en Mérida un teniente de gobernador con su alguacil y permitiera que el concejo eligiera alcaldes ordinarios y alguacil municipal, esto es, abolían el corregimiento.

Naturalmente, el resto del cabildo seguiría igual, si bien al mes siguiente (Capítulo general de Granada, 30/09/1499) acordaron limitar el salario de los regidores de la ciudad hasta los $1.000 \mathrm{mrs}$. anuales; algo que se seguía observando, al parecer, todavía en $1633 .{ }^{30}$

Entre 1499 y 1537 en Mérida el gobernador de la Provincia leonesa designaba un alcalde mayor de la ciudad y su partido, con un amplio territorio dependiente. ${ }^{31}$ Desconocía Moreno de Vargas que en torno a 1537-1538 hubo importantes movimientos en la ciudad, que aconsejaron volver a designar corregidor. La iniciativa partió del propio concejo emeritense: propusieron a la Orden la designación de corregidor, renunciando, consiguientemente, a elegir en el futuro alcaldes ordinarios; el salario del nuevo oficial real se pagaría, en parte, deduciéndolo del que gozaba el gobernador de la Provincia de León y, en parte, con 40.000 mrs. que el concejo se ofrecía a abonarle con cargo a sus propios; ${ }^{32}$ respecto a los derechos que percibían los alcaldes ordinarios (en especial, un derecho sobre la cebada) proponía que fuese a pagar a los regidores, los cuales pedían que se incrementasen de los 4 existentes al doble. ${ }^{33}$

El primer problema que se planteó para conseguir ese objetivo fue hallar el fondo del que obtener los 40.000 mrs. ofrecidos al corregidor; para ello el Consejo de las Órdenes (24/03/1537) encomendó al concejo que los buscase; el municipio constató que ya abonaban habitualmente $13.000 \mathrm{mrs}$. al letrado, al procurador y al encargado

Mérida», XXXIII Coloquios Históricos de Extremadura: Homenaje a la memoria de Isabel la Católica en el V Centenario de su muerte, Trujillo, 2005, pp. 253-280.

${ }^{30}$ Moreno, pp. 424-425.

${ }^{31}$ En la época de Moreno de Vargas pertenecían al partido de Mérida los lugares de Aceuchal, Alange, Alcuéscar, Almendralejo, Almoharín, Arroyo de San Serván, Arroyomolinos, Don Álvaro, La Garrovilla, Salvatierra, Torremocha, Salvatierra, Valverde [de Mérida] —aldea de Mérida hasta 1630—, Villafranca [de los Barros], Villagonzalo y La Zarza (Moreno, pp. 444-456).

${ }^{32}$ José M. Andrada, Los propios, comunes y baldios de Mérida en el siglo XVI, Mérida, 1986.

${ }^{33}$ Conocemos estos extremos gracias a dos fragmentos de la consulta que se presentó al Emperador, que se conservan entre los papeles del Registro del Sello de la Orden de Santiago, como borradores reaprovechados (Archivo Histórico Nacional, Órdenes Militares, Archivo Histórico de Toledo, leg. 78.243). 
del Peso de la Harina (6.000, 3.000 y 4.000 mrs., respectivamente), por lo que, ni suprimiendo estas asignaciones, lograrían alcanzar aquella cifra. ${ }^{34}$

Sin embargo, el problema económico era de poca importancia en comparación con el malestar social que existía por aquellas fechas en la ciudad, que amenazaba con provocar un derramamiento de sangre.

Al menos, esto es lo que sugiere una provisión enviada por el Consejo $(25 / 05 / 1537)$ al gobernador de la Provincia o a su teniente en el partido de Mérida y a los alcaldes ordinarios de la ciudad, además de a los electores de los cargos municipales: tres vecinos de la ciudad, Juan Martínez, Juan Gómez y Cristóbal de Orellana, habían solicitado que en las elecciones a oficios concejiles se guardasen las leyes capitulares.

Denunciaron que por no meter en las eleciones que hasta agora se an hecho de los dichos oficios en la dicha cibdad a personas de todos los estados, hidalgos e labradores e mercaderes tratantes e christianos nuevos, ha avido y ay muchos ruydos y escándalos y cochilladas e se espera que abrá sobre ello muertes de hombres.

Suplicaban que en las próximas elecciones entrasen e fuesen elegidos e nonbrados para ello los dichos christianos nuevos, syendo áviles e suficientes e concurriendo en ellos las calidades que para ser oficiales deven tener. ${ }^{35}$

Aunque no se dijera expresamente, era evidente que hacía falta en la ciudad una autoridad con el máximo rango posible para poner coto a tan explosiva situación, en la que pugnaban por entrar en el gobierno municipal no sólo los pecheros y los hidalgos, sino también los antiguos judíos, enriquecidos por el comercio.

El nombramiento del primer corregidor de los nuevos tiempos tuvo lugar el 13 de enero siguiente, recayendo el oficio en Juan Rodríguez de Cisneros. Se suprimía el teniente del gobernador en el partido, así como los alcaldes ordinarios de la villa. Consultado con el Emperador - de hecho, es notable que esta provisión la firmen el propio monarca y su secretario, el ubetense Juan Vázquez de Molina, además de los habituales: el conde de Osorno, presidente, y los consejeros Luján, Sarmiento y Anaya, junto con el secretario, Francisco Guerrero-, éste había decidido autorizar la erección del corregimiento de Mérida, con $40.000 \mathrm{mrs}$. de salario a cargo de los propios del concejo, más otros 30.000 mrs., que se rebajarían del salario del gobernador provincial, además de la mitad del derecho de la cebada, antes percibido por los alcaldes ordinarios; respecto al aumento solicitado de regidurías, sólo autorizaba a que hubiese 6 oficios, no 8, como se había suplicado. ${ }^{36}$ Consecuentemente con este nombramiento (30/03/1538), se ordenó al gobernador de la Provincia que, en lo su-

\footnotetext{
${ }^{34}$ AHT, leg. 78.243.

${ }^{35}$ AHT, leg. 78.245. Las informaciones sobre Mérida son muy numerosas en el Registro durante ese año.

${ }^{36}$ AHT, 78.253. Moreno de Vargas no comprendió demasiado bien las implicaciones que esto traía, pues, aunque supo del cambio institucional, denomina en su obra a los corregidores como gobernadores del partido de Mérida (Moreno, p. 428).
} 
cesivo, se abstuviese de ejercer su jurisdicción en Mérida y su partido, pues había corregidor propio, fuera de su dependencia jerárquica. ${ }^{37}$

El concejo emeritense, con la finalidad de embellecer la ciudad o, como ellos decían, para ennoblecerla, emprenderían de inmediato la construcción de unas casas consistoriales, con la cárcel y unas carnicerías públicas, aprovechando que deseaban levantar un aposento para el corregidor, digno de su estatus; para ello habían destinado la voluminosa cantidad de 100.000 mrs., que pretendían obtener con la venta de la bellota de sus términos baldíos. ${ }^{38}$ Esto, finalmente, sería contradicho por los pobres y necesitados de la ciudad. ${ }^{39}$ Por cierto, entre los problemas que planteó la designación de un corregidor en la ciudad estuvo la atribución de las penas de la bellota, que antes percibían los alcaldes ordinarios. ${ }^{40}$ Otro problema, tampoco baladí, fue la forma de firmar los documentos concejiles. ${ }^{41}$ El curso de las apelaciones también resultó ser problemático, al menos, en lo que se refería a las que llegaban de Almendralejo, ${ }^{42}$ así como el ejercicio de escribano de la Audiencia del corregidor. ${ }^{43}$

${ }^{37}$ El Lcdo. Diego Fernández de Hinestrosa, señor de las villas de Villar del Saz, La Olmeda y La Torre del Monje, juez de residencia de la Provincia de León, se estaba entrometiendo en la jurisdicción del corregidor (AHT, leg. 78.255).

${ }^{38}$ Dado que el gasto estaba limitado a 2.000 mrs., el concejo hubo de pedir licencia para ello al Consejo, que libró la correspondiente comisión informativa al nuevo corregidor (17/05/1538) (AHT, leg. 78.257). La licencia, finalmente, se les concedió (28/08/1538), con condición que se obtuviese esa cantidad en ese año, tomando la bellota de los baldíos de El Cuadrado, El Marchial y la dehesa de Cordobilla (AHT, leg. 78.260).

${ }^{39}$ El propio concejo solicitaría (25/10/1538) que, para obtener la cantidad requerida se vendiesen al mejor postor los baldíos de Las Abrazadas, donde, una vez recogida la cosecha, todos pudiesen entrar con sus ganados (AHT, leg. 78.262).

${ }^{40}$ Mandamiento (11/11/1538) al corregidor de Mérida o a su teniente que no lleve las dos partes de las penas de la bellota, como la llevaban los alcaldes ordinarios anteriormente, sino que se apliquen a las obras de los caños que traían agua a la ciudad, a petición del concejo. Según las ordenanzas, las penas impuestas a los que varean y cogen bellota en los encinares y montes de la ciudad, así para los puercos, como para sus casas, se repartían entre los alcaldes ordinarios y los regidores; cuando se quitaron los alcaldes se acrecentaron a 6 los 4 regimientos; desde que se nombró corregidor a Juan Rodríguez de Cisneros, en el cargo, había intentado percibir la parte que antes llevaba la justicia. Habían solicitado que se repartiesen por entero entre los seis regidores (AHT, leg. 78.263).

${ }^{41}$ Incitativa (14/08/1538) al corregidor de Mérida o a su teniente, a petición de Luis de Torres, vecino de la ciudad, que expuso que antiguamente, cuando había alcaldes ordinarios, acostumbraban que cuando se debían firmar documentos concejiles primero firmaban los alcaldes de los hidalgos y después los de los pecheros, luego los regidores de los hidalgos y luego los de los pecheros; cuando se pidió nombramiento de corregidor se estableció que, en lugar de los alcaldes ordinarios, hubiese dos regidores más (total 6), por lo que se ha abierto debate sobre el orden de firma entre ellos. Solicitaba que se mantuviese la costumbre antigua. Debería decidir el corregidor (AHT, leg. 78.260).

${ }^{42}$ Mandamiento (09/08/1538) al corregidor de Mérida o a su teniente, para que las apelaciones de menor cuantía que se presentasen ante él, provenientes de los alcaldes ordinarios de Almendralejo, las remita al regimiento de dicha villa y condene en las costas a los apelantes, a petición del concejo de esa villa. Este se quejaba de que el corregidor las remitía al regimiento de Mérida (AHT, leg. 78.260).

${ }^{43}$ Incitativa (31/10/1538) al corregidor de Mérida, a petición del bachiller Fernán Pérez, que tenía arrendada la escribanía de la audiencia durante ese año y los dos siguientes, pues a causa de la introducción 
En realidad, durante el bienio 1537-1538 la tierra emeritense debió de ser un hervidero de problemas, a los que se intentó, como venimos diciendo, poner coto con la presencia en la ciudad de un corregidor con amplios poderes. Son años en que el crecimiento demográfico y económico de las posesiones santiaguistas había dado lugar a un movimiento de emancipación concejil, que fue causa de numerosos quebraderos de cabeza para las autoridades del Consejo de las Órdenes y para los vasallos implicados. Así, sabemos que Ocaña en esos tiempos vería impotente cómo su única aldea, Villatobas (septiembre de 1537), alcanzaba el privilegio de villazgo, una vez hecha efectiva al Rey una buena cantidad (4.000 ducados). ${ }^{44}$ Mucho más traumático sería el caso de Uclés, cabeza de un importante Común y sede de una alcaldía mayor de partido: la secesión de los pueblos de la Fuente de Pedro Naharro y, sobre todo, Tarancón, ${ }^{45}$ causaron un perjuicio enorme a la villa metropolitana, pues se vio incapaz de seguir manteniendo un alcalde mayor con los recursos que le restaban, una vez perdidas las aportaciones de sus más importantes aldeas, ahora hechas villas. Así, Uclés volvió a designar alcaldes ordinarios, cuyas alzadas ahora irían ante el alcalde mayor de la Provincia de Castilla, sito en Ocaña ${ }^{46}$ Los conflictos de jurisdicción y términos serían constantes en aquellos años entre Uclés y, en especial, los vecinos de Tarancón, que prosperaron rápidamente a costa de la villa conventual.

Así pues, el mismo año en que el corregidor volvía a Mérida, Uclés perdía a su alcalde mayor, en un proceso inverso; no obstante, problemas de secesión como los que hemos visto en el Común y alfoz de Uclés también los tuvo Mérida, si bien sin que sus promotores, de momento, alcanzasen el éxito. Es gracias a estos movimientos por los que estamos informados de la existencia del Fuero extenso de Mérida.

En efecto, en una provisión (29/08/1537) ${ }^{47}$ el Consejo daba comisión incitativa al juez de residencia de la provincia, el mencionado Lcdo. Fernández de Hinestrosa, a fin de que resolviese por la vía judicial la queja presentada por el concejo de Mérida: el bachiller Fernán Pérez, que había sido letrado y abogado del municipio, se había quedado con la posesión de un Libro del Fuero que se dio a la dicha ciudad por el

de corregidor en la ciudad, en lugar del antiguo alcalde mayor, los escribanos públicos se entrometían en los casos reservados a su oficio (AHT, 78.262).

${ }^{44}$ El documento concreto debería encontrarse en el Registro (leg. 78.249), pero de ese mes de septiembre, contra lo que es habitual, sólo se conserva un puñado de provisiones. Sabemos de su existencia por la copia que se encuentra en el archivo municipal de la villa. Villatobas conoció un crecimiento prodigioso en poco tiempo; tal vez a ello, entre otros motivos, contribuyó el hecho de que se convirtiera de facto en la sede de la encomienda de Montealegre (en agosto de 1537 se ordena levantar allí las casas de aposento y bastimento del comendador de Montealegre, encomienda que carecía de lugares poblados. AHT, leg. 78.249).

${ }^{45}$ La primera mención al villazgo de Tarancón procede de diciembre de 1537 (AHT, leg. 78.253). La primera de la Fuente de Pedro Naharro en febrero del año siguiente (AHT, leg. 78.255).

${ }^{46}$ Así lo ordenó la Emperatriz, gobernadora del Reino, tras ser consultada por el Consejo (18/07/1538) (AHT, leg. 78.260).

${ }^{47}$ Ver el Apéndice III. 
señor Rey don Alonso, cuando dejó su trabajo; luego se puso al servicio de las aldeas del término emeritense, en el pleito que le seguían al concejo para dejar de contribuir en sus cargas fiscales; para recuperar el Libro fue necesario proceder a las habituales censuras eclesiásticas. Obtenido el Libro, se encontraron con que faltaban las tablas de contenido, además de los folios iniciales y finales del mismo, arrancadas porque paresciese que hera escriptura synple e que no hiziese fe. Se le acusaba, así mismo, de haber redactado un libelo injurioso contra el municipio, que fijó en las puertas del ayuntamiento, donde todo el mundo lo vio.

Pasados unos meses $(01 / 02 / 1538),{ }^{48}$ volvemos a tener noticias del desahogado letrado: había inducido a varias personas de las aldeas para que sobrepujasen en la almoneda de la escribanía de la Audiencia del alcalde mayor de la ciudad, ofreciendo por ella 400 ducados, cuando se solía arrendar por menos de $70.000 \mathrm{mrs}$., todo ello a fin que los dichos pueblos tengan escrivano de su mano para saber ellos y el dicho bachiller lo que se hiziere público e secreto. En este caso se ve que llovía sobre mojado, pues el Consejo debía estar bien informado de las andanzas del descarado bachiller, cuando, sin más preámbulos, ordenó al alcalde mayor que no recibiera como escribano a nadie que no hubiese sido antes examinado por el Consejo — hasta ahí nada extraordinario- y se supiese que era persona de buena fama, vida e costunbres e de tal hedad e calidad e parentesco, a quyen el derecho e premáticas e leyes destos Reynos no proyben ni vedan entregar ny exercer el dicho oficio de escrivanía.

Sin embargo, el asunto ya había pasado antes por la Chancillería de Granada, la cual había ordenado a comienzos de 1536 al díscolo letrado que entregase el libro del Fuero para su utilización en dos procesos que la ciudad de Mérida seguía por la percepción del derecho del trigo y la cebada; uno con las villas de Lobón y Montijo y otro con las aldeas de Almendralejo, Arroyo, Puebla de la Calzada, Alguijuela, Garrovilla, Aljucén, Carrascalejo, Mirandilla, Trujillanos, San Pedro, Valverde y Don Álvaro. Unos meses después consiguieron los oidores de la Audiencia que el texto del Fuero fuera exhibido ante ellos, lo cual no fue óbice para que el concejo de Lobón lo tachase de falso. ${ }^{49}$

\footnotetext{
${ }^{48}$ Ver el Apéndice IV. A pesar de todas estas cautelas, tal y como hemos indicado en la nota 43, el mencionado bachiller se hizo con la escribanía de la Audiencia ese año.

${ }^{49}$ Ver Apéndices I y II. Contamos con varias provisiones de trámite de ambos procesos, si bien las ejecutorias aún no han sido localizadas. El 8 de agosto de 1536 se envió, a petición de las aldeas, al receptor Diego Hurtado de Fuentes para que en plazo de 160 días tomase las declaraciones de sus testigos (Archivo de la Real Chancillería de Granada, legajo 5.605); el asunto se complicó en pocos días, ya que las aldeas habían intentado notificar a Pedro González, alcalde ordinario de Mérida, una carta de emplazamiento, pero ningún escribano de la ciudad se atrevía a hacerlo, por lo que las aldeas decidieron acudir a otro escribano foráneo, ante lo cual a los oficiales emeritenses sólo se les ocurrió agredir al fedatario en la plaza pública, lo asieron por los cabezones de la camisa, le tiraron al suelo y le injuriaron de palabra y obra. Estaban en juego, según las estimaciones de las aldeas, 1.800 fanegas de cebada y otras tantas cuartillas de trigo. Hurtado de Fuentes recibiría el encargo de recibir las probanzas de todos estos hechos (ARChG, legajo 5.604).
} 
Pues bien, yendo a lo que nos interesa en este trabajo, sabemos que a la altura de 1537, si hemos de dar plena fe a la queja del municipio emeritense - y nada nos lo impide-, existía un Libro de Fuero, atribuido a un Rey Alfonso, de cierta enjundia, pues tenía tabla de contenidos, y que estaba autenticado, ya que se le habían quitado los folios del principio y del fin, donde constarían el nombre del monarca que lo concibió y las firmas que lo avalaban así.

Dado que ese ejemplar — recuperado finalmente por el concejo, sin las tablas y folios mencionados- no nos ha llegado, ni parece que se supiera de su existencia un siglo más tarde (1633), tan sólo podemos hacer conjeturas sobre el mismo.

Lo cierto es que, gracias a la adición de los tres últimos artículos del fuero breve de 1253, sabemos que en un momento indeterminado - ¿en tiempos del maestre don Vasco Rodríguez Coronado (1327), en cuyo citado privilegio se manda que los pueblos paguen sus tributos en la ciudad, según su fuero, coincidiendo, además, con la política de redacción de fueros, que se dio durante el reinado anterior de Fernando IV?- existía un Fuero extenso, que se aplicaba en los juicios producidos en Mérida, según los usos acostumbrados en Cáceres. Para ello, establecía en primer lugar el juicio de albedrío de los alcaldes y, en caso de alzada, el echarse al Fuero, como se solía decir, esto es, acudir al libro a ver qué solución recogía para ese tema sobre el que se litigaba. Está claro que sólo se podía establecer esa norma - como ocurre con el Fuero de Cuenca y sus derivados- para el caso de que existiera un texto de una entidad importante.

Sabemos que se atribuía a un Rey Alfonso; dada la importancia que se daba a la antigüedad de los fueros, a fin de prestarles mayor autoridad, me quedan pocas dudas de que se referían a Alfonso IX de León, conquistador de Cáceres y Mérida. Así se atribuía la máxima valía al Fuero, pues se situaba su concesión e, incluso, su redacción

Al tiempo que denunciaban el atropello al escribano, ganaron otra provisión el mismo día (16 de agosto) para que en Mérida se guardase capítulo de las Cortes de Toledo de 1525 a fin de que los ofíciales de concejo no fueran fiadores de gobernadores, corregidores y demás justicias, algo de lo que acusaban a Diego López, escribano de la audiencia del alcalde mayor de la ciudad, al que había fiado (Ibidem). En el año siguiente, en el proceso de Mérida con las dos villas, ambas partes obtuvieron compulsorias de distintas escrituras tendentes a probar: las villas, que tenían términos y jurisdicción propios, separados de los de la ciudad, y ésta que las villas habían sido y eran sus vasallas, donde se aplicaban las ordenanzas emeritenses: previllegio que la dicha cibdad tenya, que estava en el archivo e arca della, e de las mercedes que la dicha cibdad abya hecho a las dichas villas, como a sus vezinos, de roças e otros heredamientos e de las besytaciones que avía hecho de sus términos, que confinavan con la cibdad de Badaxoz facia la parte donde estaban las dichas villas, e de los procesos e sentencias que los alcaldes hordinarios de la dicha cibdad abian hecho contra bezinos de las dichas villas de penas en que avían yncurrido, conforme a las hordenanças de la dicha cibdad, e sobrello avian sydo acusados e sentenciados, como sus vasallos (ARChG, legajo 5.611, 24 de marzo; y legajo 5.619, 18 de agosto).

La última provisión localizada, de momento, sobre este caso, va datada en 15 de septiembre del mismo año 1537, cuando Mérida consiguió auto de la Chancillería que denegaba lo pedido por las villas de Lobón y Montijo, acerca de que el trigo y cebada de la recaudacion de ese año no fuese entregado a la ciudad, sino que quedase consignado en las villas (ARChG, legajo 5.621). 
en tiempos del último monarca leonés; no cabía mayor antigüedad, y se atribuía a un rey, no a un arzobispo ni a un maestre, como hubiera sido lo lógico, de acuerdo con la carta de población.

Podemos, por tanto, hablar de la existencia de un desconocido Fuero extenso de Mérida, atribuido al Rey Alfonso IX; ahora bien, ¿a partir de qué modelo se redactaría el texto? Desde luego, no cabe pensar que el Fuero de Mérida naciese completo a mediados del siglo XIII, aunque contase con un modelo claro y cercano. A mi modo de ver, el modelo debió ser el tantas veces mencionado Fuero de Cáceres ${ }^{50}$ pero ninguno de los dos nacería con el volumen que luego alcanzarían, ni podría atribuirse su redacción a la cancillería de dicho Rey. Como ocurre con el señero Fuero de Cuenca y tantos otros, estos fueros extensos serían el resultado de un largo proceso de redacción, el cual, para concederle la máxima autoridad y antigüedad posibles, se personificó en la figura de dicho monarca.

Finalmente, en cuanto al contenido del Fuero, cabe suponer que se incluiría en su seno - si es que no se hizo un traslado más o menos completo del Fuero de Coria o del Fuero de Cáceres - el conjunto de privilegios recibidos de los maestres santiaguistas hasta el momento en que la redacción quedase fijada, que entiendo debió de producirse en el primer tercio del siglo XIV.

\footnotetext{
${ }^{50}$ Cáceres recibió fuero breve en 12/03/1231 de manos de Alfonso IX, luego confirmado y ampliado por Fernando III; se conserva, además, un fuero extenso, en romance, basado en el Fuero de Coria, también atribuido a Alfonso IX (Barrero y Alonso, Textos de derecho local, p. 170).
} 


\section{APÉNDICE I}

\section{6/02/12. Granada}

Ynserto un abto para que el bachiller Fernand Pérez, vezino de Mérida, dé un Fuero dentro de tercero día e, si no, que dentro de quinze días venga personalmente a esta Corte.

Escrivano, Fernán Peres Gallego

ARChG, legajo 5.599.

Don Carlos e doña Juana, su madre, etc. A vos el bachiller Fernand Pérez, vezino de la cibdad de Mérida. Salud e gracia. Sepades que pleito está pendiente en la nuestra Corte e Chancillería, ant'el presydente e oidores, que resyde en la cibdad de Granada, entre el concejo, justicia e regimiento de la cibdad de Mérida e su procurador en su nonbre, de la una parte, e el concejo, justicia e regidores, oficiales e omes buenos de la villa de Lobón e su procurador en su nonbre, de la otra, sobre razón del derecho de cierto trigo e cebada que los vezinos de la dicha cibdad de Mérida les piden e demandan por virtud de una escriptura de Fuero e sobre las otras cabssas e razones en el proceso del dicho pelito contenydas, en el qual por los dichos nuestro presydente e oydores han sydo dados abtos en vista e en grado de revista, por los quales fue mandado que la parte de la dicha cibdad de Mérida no usase de una nuestra carta executoria, porque el dicho Fuero no lo avía presentado, como le avía sydo mandado; después de lo qual assí por parte de la dicha villa de Lobón avían fecho ciertas ynformaciones e diligencias, por las quales constaba claro que el dicho Fuero sobre que hera el dicho pleito estava en vuestro poder o sabíades d'él e que lo avíades tomado, syendo letrado de la dicha cibdad, en el qual por amas las dichas partes fue dicho e alegado cada una dellas en guarda de su derecho fasta tanto qu'el dicho pleito fue conclusso e por los dichos nuestro presidente e oidores visto, dieron e pronunciaron en el dicho negocio un abto, su tenor del qual es este que se sigue:

«En la cibdad de Granada, veinte e syete días del mes de enero de mill e quinyentos e treinta e seys años, visto por los señores del Abdiencia de SS.MM. el processo de pleito entr'el concejo, justicia e regidores de la villa de Lobón e la última petición por su parte presentada e lo a ello respondido por parte de la cibdad de Mérida, dixieron que mandavan e mandaron que se dé provissión de SS.MM. para que vaya desta Corte un recetor, el qual tome e resciba la ynformación que le fuere dada por parte del dicho concejo de Lobón sobre lo tocante al Fuero que la dicha cibdad de Mérida dizen que tienen. E, sy la parte de la dicha cibdad de Mérida quisiere provissión para dar ynformación de lo contrario, se le dé [e] el dicho recetor la resciba e que juren las unas partes e las otras sobre lo susso dicho e los procuradores e letrados desta Corte e que se faga todo dentro de treinta días primeros syguientes, e el recebtor se parta dentro de tercero día para lo hazer e que no se les ha de dar más término.

E otrosy mandaron qu'el bachiller Fernand Pérez dé e entregue a la parte de la dicha cibdad de Mérida la escriptura del dicho Fuero, que dizen que rescibió, lo qual dé e entregue dentro de tercero día después que fuere requerido e, no dándolo, mandavan al dicho bachiller que dentro de quinze días después de requerido venga e parezca personalmente ante los dichos señores e, assí venido, no se absente ny vaya syn su licencia e mandado, so pena de cinquenta mill mrs. para la Cámara e fisco de SS.MM.; e, hecha la dicha ynformación, se traia ante los dichos señores para que se vea e provea sobre ello lo que fuere justicia».

E fue por ellos acordado que devíamos mandar dar esta nuestra carta para vos, el dicho bachiller Fernand Pérez, en la dicha razón. E Nos tobímoslo por bien, porque vos mandamos que luego que con ella por parte de la cibdad de Mérida fuéredes requerido, veays el dicho abto e mandamyento dado e pronunciado por los dichos nuestro presydente e oidores que de susso en esta nuesta carta va encorporado, e en quanto toca al exivir del dicho Fuero e en lo demás que a vos toca lo guardéys e cunpláys e fagáys guardar e cunplir en todo e por todo, como en ello se contiene e contra el tenor e forma dello ni de lo en ella contenydo no vayáys ni passéys ni consintáys yr ny passar por alguna manera, so las penas en el dicho abto contenidas e más so pena de la nuestra merced e de otros cinquenta mill mrs. para la nuestra Cámara e fisco, so la qual mandamos a qualquyer escrivano e recebtor de la dicha nuestra Ab- 
diencia que para esto fuere llamado que dé ende al que vos la mostrare testimonio sygnado con su signo, porque Nos sepamos en cómo se cunple nuestro mandado. Dada en la cibdad de Granada, a doze días del mes de hebrero de mill e quinientos e treynta e seys años.

Libraronla los señores oydores licenciatus Muñoz, el licenciado Arrieta, el doctor Gálvez, el licenciado Esquibel. Registrada, el licenciado Johán Alvares de Alarcón.

\section{APÉNDICE II}

\section{6/07/24. Granada}

Ynsertos dos autos para que la villa de Lobón pague a la cibdad de Mérida el derecho del trigo e cevada, conforme al privilegio que tiene Mérida.

Secretario, Fernán Peres Gallego

Derechos registro .XXVII.

ARChG, legajo 5.603.

Don Carlos, etc. A todos los corregidores, asystentes, governadores, alcaldes e otros juezes e justicias qualesquier, ansy de la villa de Lobón como de todas las otras cibdades, villas e logares destos nuestros Reynos e señoríos, e a cada uno de vos a quyen esta nuestra carta fuere mostrada. Salud e gracia. Sepades que pleito está pendiente en la nuestra Abdiencia e Chancillería que está e reside en la cibdad de Granada, con el concejo, justicia e regidores e oficiales e onbres buenos de la dicha villa de Lobón e su procurador en su nonbre e el concejo, justicia e regidores e oficiales e omes buenos de la cibdad de Mérida o su procurador en su nonbre de la otra, sobre razón del trigo e cebada que la dicha cibdad pide a cada un vezino de la dicha villa e su tierra e sobre las otras cabsas e razones en el proceso del dicho pleito contenidas, en el qual por anbas las dichas partes fue dicho e alegado cada una dellas en guarda de su derecho hasta tanto qu'el dicho pleito fue concluso e por los dichos nuestro presidente e oidores fueron dados los abtos en la vista e revista para que en el ynterin llevase la dicha cibdad el dicho derecho, e dello se llevó una carta executoria.

E después de lo qual por parte de la dicha villa de Lobón nos fue suplicado e pedido por merced mandásemos al procurador de la dicha cibdad que esibiese en la dicha cibdad anthe los dichos nuestro presidente e oydores el Fuero original por donde llevava el dicho derecho; e sobre ello fueron dados abtos en vista e revista, por los quales mandamos suspender la dicha nuestra carta esecutoria e que la dicha cibdad no llevase el dicho derecho hasta tanto que fuese esibido.

Después de lo qual pareció la parte de la cibdad de Mérida e nos fizo relación por su petición que anthe los dichos nuestro presidente e oydores presentó diziendo que por nos se avía mandado suspender la dicha executoria hasta tanto que esiviesen el dicho Fuero, el qual ysivía e d'él fizo muestra anthe nos originalmente, por ende que nos pedía e suplicava mandásemos rebocar la dicha suspensión e que sus partes usasen e pudiesen usar de la dicha carta executoria, como antes usavan della e sobre todo nos pidió cunplimiento de justicia.

De la qual dicha petición por los dichos presidente e oydores fue mandado dar treslado a la parte de dicha villa, para que [para e para se la dar] dixese de su justicia; contra lo qual por vuestra parte fue dicho e alegado lo contenido e sobrello el dicho pleito fue concluso e por los dichos nuestro presidente e oydores, visto el proceso del dicho pleito, dieron e pronunciaron un auto, su thenor es este que se sigue:

«En la cibdad de Granada, a catorze días del mes de jullio de mill e quinientos e treynta e seys años, visto por los señores oydores del Abdiencia de SS.MM. el proceso de pleito que ant'ellos pende entre el concejo, justicia e regidores, oficiales e onbres buenos de la cibdad de Mérida e Francisco de Santiestevan, su procurador, en su nonbre, de la una parte, e el concejo, justicia e regidores, oficiales e onbres buenos de la villa de Lobón e Gastón de Cayzedo, su procurador, en su nonbre, de la otra, dixeron que devían mandar e mandaron dar carta e provisión de SS.MM. para que la dicha cibdad de Mérida pueda usar e use de la carta esecutoria de SS.MM. del ynterin que sobre este negocio les fue dada para 
poder en el dicho ynterin cobrar e llevar el trigo e cebada sobre que es este pleito, lo qual se haga e cunpla syn enbargo de la suspensyón que está puesta para que no se pudiese usar de la dicha esecutoria hasta tanto que la parte de la dicha cibdad esiviese el Fuero de la dicha cibdad.

E otrosy dixeron que devían de res[cibir e res]cibieron a la parte de la dicha cibdad de Mérida a prueva de la verivicación de la dicha escritura, que dize que es el Fuero, que por su parte fue esivido, e a la otra parte a prueva de lo contrario dello, sy quisyeren. E anbas las dichas partes e a cada una della a prueva de todo aquello que de derecho deven de ser rescibidos a prueva e provado les aprovechará, según el estado en que está este dicho pleito, salvo jure et ynpertinentivum et non admitendorun, para la qual hazer le dieron e asynaron plazo e término de veynte días primeros syguientes por todos plazos e término perentorio, con apercibimiento que no les será dado ni prorrogado, e que desde agora quede fecha publicación e concluso para que se trayga luego anthe los dichos señores para lo ver e proveer sobrello lo que fuere justicia. E mandaron que las dichas partes enbíen a ver presentar, jurar e conoscer los testigos que la una parte presentare contra la otra, sy quisyere».

El qual dicho auto fue notificado a los procuradores de las dichas partes, del qual dicho auto por parte de la dicha villa fue suplicado e por una petición de suplicación que su procurador en su nonbre ante los dichos nuestro presidente e oydores presentó diziendo que, hablando con el acatamiento que devía, en quanto hera o podía ser en perjuyzio de sus partes, se devía de enmendar e revocar, lo uno, porque no estava el proceso en tal estado; lo otro, porque todos los dichos autos [que] se avían proveído avía sido por no parescer el dicho Fuero, que las partes contrarias avían escondido, en que ellos e sus testigos se fundavan, e no hera dada, syno que nuebamente se devía proveer en lo del entretanto e se avía de mandar guardar sus autos dados en fabor de sus partes; lo otro, porque pues la cabsa donde se avían probeído los dichos autos segundos estavan claros de todo ello y estar las partes contrarias conbencidos e no thener derecho a lo que pedían, no avía por qué quitar suspensyón; lo otro, porque, aunque los dichos autos se avían probeído porque no avían esivido las partes contrarias la escritura del Fuero que dezían thener, avíanse de consyderar la continuación e avían thenido dello para que la escritura paresciese e aquello que en lo demás abía de obrar para la cabsa se viese e determinase primero se viese sobre lo de la suspensyón; lo otro, porque sy aunque no se tuviese de rebocar los autos pronunciados lo mysmo que se avían movido para suspenderlos por la continuación, avíase de mover agora por los que estava decidido e porque el pleito estava concluso en difinitiva para se determinar. Por ende, que nos pedía e suplicava mandásemos enmendar e revocar el dicho auto e hazer segund que por su parte estava pedido e sobre todo nos pedió conplimiento de justicia. E por quanto la parte de la cibdad de Mérida concluyó sin enbargo de la dicha petición el dicho pleyto fue concluso e por el dicho nuestro presidente e oydores a esto dieron e pronunciaron otro abto en grado de revista, su thenor del qual es este que se sigue:

«En la cibdad de Granada, veynte e un días del mes de junyo [sic] de mill e quinyentos e treynta e seys años, visto por los señores oydores de la Abdiencia de SS.MM. el proceso de pleyto entre el concejo, justicia e regidores, oficiales, omes buenos de la cibdad de Mérida e Francisco de Santestevan, su procurador, en su nonbre, de la una parte, y el concejo, justicia e regidores de la villa de Lobón e Gastón de Cayzedo, su procurador, en su nonbre, de la otra, dixeron que devían confirmar e confirmaron en grado de revista el abto que sobre este negocio por los dichos señores fue dado e pronunciado, con este aditamento e declaración: que ansí mismo recebían a prueva a la parte del dicho concejo de Lobón de la falsedad e de todo lo demás por su parte dicho e alegado contra la escritura del Fuero de la dicha cibdad de Mérida, e que los testigos vengan personalmente ante los dichos señores, y en quanto a las costas que la parte del dicho concejo de Lobón a hecho por respeto de la dilación que [ha] avido en se esebir el dicho Fuero la parte de la dicha cibdad de Mérida, lo reservavan e reservaron para lo determinar sobrello en la difinitiva lo que fuere justicia; e con el dicho aditamento mandaron qu'el dicho abto se guarde e cunpla y esecute, como en él se contiene, e no hizieron condenación de costas contra ninguna de las partes».

Después de lo qual paresció la parte de la dicha cibdad de Mérida e nos suplicó e pidió por merced le mandásemos dar nuestra carta e provisyón real de los dichos abtos, para que en todo e por todo le 
fuesen guardados, conplidos y esecutados o que sobrello le probeyésemos como la nuestra merced fuese. Lo qual, visto por los dichos presidente e oydores acordaron que devíamos mandar dar esta carta para vos en la dicha razón e nos tobímoslo por bien, porque bos mandamos que luego que con ella por parte de la dicha cibdad de Mérida fuéredes requerido o requeridos, veays los dichos abtos que en vista e grado de revista entre las dichas partes e sobre los dichos dados e pronunciados por los dichos nuestro presidente e oydores, que de suso está e ban encorporados e nuestra carta executoria dada a la parte de la dicha cibdad de Mérida, de que en el dicho abto de vista se haze minción e los guardéys e cunpláys y esecutéis e hagáys guardar, conplir y esecutar e llevar e llevéis a pura e devida esecución, con efeto, en todo e por todo, segund e que en los dichos abtos e carta executoria se contiene, e contra el thenor e forma dellos ni de lo en ellos contenido no vayáys ni paséis, ni consyntáys yr ni pasar por alguna manera, so las penas en la dicha nuestra carta executoria contenidas, e más so pena de la nuestra merced e de otros cinquenta mill mrs. para la nuestra cámara e fisco, so la qual dicha pena, etc. Dada en Granada, a veinte e quatro días de el mes de jullio de quinyentos e treinta e seys años.

Libráronla los licenciados Muñoz e Arreta e dotor Galves, oydores. Va testado o dizía «ante he dicho». Va escrito este registro en dos pliegos de papel.

Registrada. El licenciado Johán Alvares de Alarcón.

\section{APÉNDICE III}

1537/08/29. Valladolid

Comysyón al jués de resydencia de la provincia de León que por su persona aya ynformación y haga justicia, a pedimiento del concejo de Mérida.

El concejo de Mérida, Valladolid, agosto de .MDXXXVII. años

AHN, OO.MM., AHT, leg. 78.248.

Don Carlos, etc. A vos el licenciado Diego Fernandes de Ynystrosa, cuyas son las villas del Villar del Saz y El Olmeda y la Torre el Monje, my jués de resydencia de la provincia de León. Salud e gracia. Sepades que Lope Mexía, en nombre del concejo, justicia e regidores, oficiales y omes buenos de la ciudad de Mérida, me hizo relación por su petición que en el my Consejo de la dicha Horden presentó disiendo que el bachiller Fernán Peres, vezino de la dicha ciudad, fue letrado y abogado della y que el tiempo que sirvió el dicho cargo de letrado tuvo en su poder un Libro del Fuero que se dio a la dicha ciudad por el señor rey don Alonso, de gloriosa memoria, en el qual dicho libro diz que está declarado lo que los vezinos de los lugares de la juredición de la dicha ciudad son obligados a pagar a los alcaldes hordinarios della, y que después quel dicho bachiller Fernán Peres dexó de ser letrado de la dicha ciudad dis que hurtó el dicho Libro del Fuero della y se concertó con los dichos lugares para que moviesen pleito a la dicha ciudad para no pagar lo que ansy son obligados, conforme al dicho Fuero, diziendo no aver cabsa ny razón para ello, e que con muchas excomunyones que se an hecho se descubrió cómo estava en poder del dicho bachiller el dicho Libro del Fuero, y que se dio a un freile para que lo diese, del qual dicho Libro dis que estavan quytadas las tablas y ciertas fojas del principio e fyn dél porque paresciese que hera escriptura symple e que no hiziese fe, e que, demás de lo susodicho, el dicho bachiller por razón del dicho pleito escrivió una carta ynjuriosa e afrentosa contra la dicha justicia e regidores e oficiales de la dicha ciudad y contra las otras personas que él dezía que les parescía mal lo susodicho, firmada de su nombre, que dis que fue echada en las Casas del Ayuntamiento de la dicha ciudad para que la viesen quando entrasen en ellas, del que en el dicho my Consejo fue fecha presentación, por lo que dis que el dicho bachiller Fernán Peres avía caydo e yncurrido en muchas y graves penas ceviles e crimynales e la dicha ciudad a rescivido e recive mucho agravio y perjuizio por el ynterese que dello se le sygue.

Por ende, que me suplicava e pedía por merced mandase embiar desta Corte un jués pesquysydor para que procediese contra el dicho bachiller y contra todas las otras personas que en lo susodicho hallase culpantes y los castigase conforme a justicia, o como la my merced fuese. 
E en el dicho my Consejo fue acordado que devía mandar dar esta my carta para vos en la dicha razón, e yo tóvelo por bien, por la qual vos cometo e mando que como con ella fuéredes requerido vos por vuestra persona, syn lo cometer a otro alguno, ayáys ynformación cerca de lo susodicho y sepáys cómo y de qué manera a pasado e pasa e ansy, avida la dicha ynformación, sy por ella hallardes culpados alguna persona o personas, prendeldes los cuerpos, e, llamadas e oydas las partes a quien tocare, brevemente, syn dar lugar a dilaciones, hagáis e administréis cerca dello entero cumplimiento de justicia, por manera que la parte que la toviere la aya y alcance y por defeto della no tenga cabsa de se me venyr sobrello a quexar, para lo qual, sy necesario es, vos do poder complido con sus yncidencias e dependencias, anexidades e conexidades. E no fagades ende al por alguna manera, so pena de la my merced e de dies myll mrs. para la my Cámara.

Dada en Balladolid, a .XXIX. de agosto de .MDXXXVII. años.

El Clavero. Luxán. Sarmiento. Anaya. Secretario, Guerrero.

\section{APÉNDICE IV}

\section{$1538 / 02 / 01$. Valladolid}

Al alcalde mayor del partido de Méryda, que no resciba a ningunas personas por escrivanos de su Audiencia syn que primero se presenten en el Consejo y sean en él examynados e se sepa las personas que son e de qué vida e costunbres.

El concejo de Mérida. Valladolid, hebrero, .MDXXXVIII. años.

AHN, OO.MM., AHT, leg. 78.254.

Don Carlos, etc. A vos el alcalde mayor que es o fuere del partido de la cibdad de Mérida. Salud y gracia. Sepades que Francisco de Vera, en nonbre del concejo de la dicha cibdad, me hizo relación por su petición, que en el my Consejo de la dicha Horden presentó, diziendo que en la dicha cibdad reside un letrado que se dize el bachiller Hernán Pérez y que por yntercesión suya las aldeas della traen muchos y diversos pleitos con la dicha cibdad en la nuestra Audiencia real que reside en la cibdad de Granada, e que el dicho bachiller ynduzió a las dichas aldeas e personas particulares dellas que tienen más parte que pujasen e arrendasen la escrivanía de vuestra Audiencia, quel comendador Francisco Çapata tiene de my por merced, e que, no baliendo más de setenta mill mrs., dieron por ella quatrocientos ducados por este presente año a fin que los dichos pueblos tengan escrivano de su mano para saber ellos y el dicho bachiller lo que se hiziere público e secreto, de que la dicha cibdad e vezinos della han rescibido e resciben mucho agravio e daño, suplicándome lo mandase proveer e remediar, como la my merced fuese.

Y en el dicho my Consejo fue acordado que devía mandar dar ésta mi carta en la dicha razón, e yo tóvelo por bien, porque vos mando que no rescibáys al uso y exercicio de la escrivanía de vuestra Audiencia e juzgado a persona alguna sin que primero parezca e se presente personalmente en el dicho my Consejo y sean en él examynados e se sepa sy son personas de buena fama, vida e costunbres e de tal hedad e calidad e parentesco, a quyen el derecho e premáticas e leyes destos Reynos no proyben ni vedan entregar ny exercer el dicho oficio de escrivanos.

E los unos ni los otros no fagades ende al por alguna manera, so pena de la mi merced e de diez mill mrs. para la mi Cámara. Dada en Valladolid, a primero día de hebrero de .MDXXXVIII. años.

El Conde don García Manrique. Licenciatus Luxán. Licenciatus Sarmiento, Dotor Anaya. Secretario, Guerrero. 